\title{
PENGEMBANGAN PERANGKAT PEMBELAJARAN EJAAN UNTUK MENINGKATKAN KEMAMPUAN BERPIKIR TINGKAT TINGGI
}

\author{
DEVELOPMENT OF SPELLINGEDUCATION TOOL TO IMPROVE HIGHER ORDER \\ THINKING SKILLS
}

\author{
Markhamah, Main Sufanti, Atiqa Sabardila, Winarni
}

Fakultas Keguruan dan Ilmu Pendidikan

Universitas Muhammadiyah Surakarta

Jalan A. Yani, Pabelan, Kartasura, Sukoharjo, Indonesia 57169

markhamah@ums.ac.id

\begin{abstract}
(Naskah diterima tanggal 7 April 2020, direvisi terakhir tanggal 8 Februari 2021, dan disetujui tanggal 3 Mei 2021)

DOI: https:/ / doi.org/10.26499/wdprw.v49i1.510
\end{abstract}

\begin{abstract}
This research aims to produce a spelling education tool that meets the criteria of (a) validity, (b) practicality, and (c) effectiveness to improve the higher-order thinking skills of school students. This research is development research that refers to the Borg $\mathcal{E}$ Gall model which consists of 10 steps. The developed tool included a set of syllabus, class activity planning, worksheets for students, and tests. The subjects of this study were fourth-grade students of Izzatul Islam Getasan Elementary, Semarang Regency. The data collection technique utilized methods of focused group discussion (FGD) and product assessment. Data analysis utilized descriptive quantitative and descriptive qualitative techniques. Research results indicate that the spelling education tool developed successfully met the criteria of (a) validity with a very good category, based on validity assessment by experts in education and linguistics. The tool developed also met the criteria of (b) practicality with good category, based on the scale of responses from teachers and students. The tool developed also met the criteria of (c) effectiveness with a very significant effect in improving students' higher-order thinking skills, based on the results of the effectiveness test using the Mann-Whitley statistical test. Thus it can be concluded that the development of this spelling education tool has successfully met the targeted criteria to improve the higher order thinking skills of school students.
\end{abstract}

Keywords: learning tools; spelling; higher order thinking skills

\begin{abstract}
Abstrak
Tujuan penelitian ini adalah menghasilkan perangkat pembelajaran ejaan yang memenuhi kriteria (a) valid, (b) praktis, dan (c) efektifuntuk meningkatkan kemampuan berpikir tingkat tinggi siswa sekolah. Penelitian ini merupakan penelitian pengembangan yang mengacu padamodelBorg\&Gallyang terdiri atas 10 langkah. Perangkat yang dikembangkan meliputi silabus, Rancangan Pelaksanaan Pembelajaran (RPP), Lembar Kerja Peserta Didik (LKPD), dan penilaian. Subjek penelitian ini adalah siswa kelas IV SDIT Izzatul Islam Getasan, Kabupaten Semarang.Teknik pengumpulan data menggunakan metode focused group discussion (FGD) dan penilaian produk. Teknik analisis data menggunakan teknik deskriptif kuantitatif dan deskriptif kualitatif. Hasil penelitian menunjukkan bahwa perangkat pembelajaran ejaan yang dikembangkan berhasil memenuhi kriteria (a) valid dengan kategori sangat baik, berdasarkan penilaian uji validitas dari ahli pendidikan dan ahli bahasa. Perangkat yang dikembangkan juga memenuhi kriteria (b) praktis dengan kategori baik, berdasarkanskala respon dari guru dan siswa.
\end{abstract}


Perangkat yang dikembangkan juga memenuhi kriteria(c) efektif dengan pengaruh yang sangat signifikan dalam meningkatkan kemampuan berpikir tingkat tinggi siswa, berdasarkan hasil pengujian efektifitas melalui uji statistika Mann-Whitley. Bisa disimpulkan bahwa pengembangan perangkat pembelajaran ejaan ini berhasil memenuhi kriteria yang ditargetkan untuk meningkatkan kemampuan berfikir tingkat tinggi siswa sekolah.

Kata Kunci: perangkat pembelajaran; ejaan; kemampuan berpikir tingkat tinggi

\section{Pendahuluan}

Ejaan memiliki hubungan yang erat dengan bahasa, khususnya makna kalimat. Ketepatan penggunaan ejaan menunjukkan bahwa penutur adalah seorang pemakai bahasa yang baik. Penggunaan ejaan yang tepat dapat membantu mewujudkan indikator kesantunan berbahasa.Salah satu indikator kesantunan berbahasa, menurut Pranowo, adalah penutur. Penutur berupaya agar tuturan dapat diterima oleh mitra tutur (Lestari 2017). Agar tuturan bisa diterima oleh mitra tutur, khususnya tuturan tulis, tuturan itu harus menerapkan norma pemakaian bahasa, termasuk ejaan. Untuk bisa menerapkan ejaan yang tepat, seorang penutur perlu mendapatkan pelatihan. Pelatihan yang dimaksud, di antaranya dapat dilaksanakan melalui pelatihan penggunaan bahasa atau pembelajaran bahasa.

Para pemerhati penggunaan Bahasa Indonesia menyatakan bahwa penggunaan Bahasa Indonesia masih memprihatinkan. Para tokoh yang seharusnya memberikan contoh penggunaan Bahasa Indonesia yang baik dan benar ternyata belum seperti yang diharapkan. Penggunaan bahasa Indonesia pada ruang publik juga belum membanggakan (Sriyanto 2015).

Untuk itu, Badan Pengembangan dan Pembinaan Bahasa berupaya keras membangkitkan kembali kecintaan dan kebanggaan masyarakat Indonesia terhadap bahasa Indonesia.Salah satu upaya yang dilakukan adalah meningkatkan mutu penggunaan
Bahasa Indonesia untuk mencapai penggunaan Bahasa Indonesia yang baik dan benar.

Penggunaan bahasa Indonesia yang baik adalah penggunaan Bahasa Indonesia yang sesuai dengan situasi komunikasi. Penggunaan Bahasa Indonesia yang benar merupakan penggunaan Bahasa Indonesia yang sesuai dengan kaidah bahasa Indonesia.Kaidah bahasa Indonesiamenurut Baryadi meliputi ejaan, kata, frasa, dan kalimat (Baryadi 2017).

Ejaan adalah kaidah cara menggambarkan bunyi-bunyi (kata, kalimat, dan sebagainya) dalam bentuk tulisan (hurufhuruf) serta penggunaan tanda baca(KBBI 2020). Dengan kata lain, ejaan merupakan aturan menulis kata-kata dengan menggunakan huruf menurut tata cara disiplin ilmu bahasa (Tarigan, 2009: 2).

Latihan untuk menerapkan penggunaan ejaan dilakukan di antaranya pada pembelajaran bahasa Indonesia, khususnya keterampilan menulis. Pembelajaran keterampilan menulis di sekolah dasar dikelompokkan menjadi dua kelompok, yaitu pembelajaran ketrampilan menulis permulaan dan menulis lanjut.Pembelajaran menulis lanjut dilaksanakan pada kelas III sampai VI. Pembelajaran ini bertujuan agar siswa dapat menulis dengan mengembangkan ide secara sistematis dengan mengacu kepada penggunaan ejaan yang benar(Puswitasari dkk., 2016).

Hal yang tidak kalah penting untuk diperhatikan dalam pembelajaran menulis, khususnya ejaan, adalah kebermaknaan pembelajaran tersebut bagi siswa. Pembe- 
lajaran haruslah mampu menjawab tantangan zaman.Pembelajaran keterampilan menulis dengan mengintegrasikan kompetensi abad XXI harus dilaksanakan oleh pendidik untuk mempersiapkan peserta didik agar mampu bersaing pada masanya. Integrasi keterampilan menulis dan kompetensi abad XXI menjadi sebuah keharusan, termasuk pada pembelajaran ejaan.

Salah satu upaya meningkatkan kualitas peserta didik padaabad XXI adalah dengan membekali keterampilan berpikir tingkat tinggi. Keterampilan berpikir tingkat tinggimerupakan rangkaian tindakan yang secara tidak langsung memanipulasi ide dan informasi.Manipulasi ide ini pada akhirnya melahirkan konsep dan implikasi baru. Konsep ini mengalami pergeseran dari paradigma transfer ilmu menjadi konstruksi ilmu (Istiqomah 2018).

Dinamisnya perkembangan zaman berimplikasi pula pada paradigma keterampilan berpikir tingkat tinggi.Tahapan berpikir senantiasa cepat bergerak dan mengalami penyesuaian dan penyesuaian itu perlu dinyatakan dalam kata kerja.Untuk menyatakan penyesuaian itu diperlukan taksonomi Bloom sebagaimana dinyatakan oleh Anderson \& Krathwohl (Anderson and Krathwohl 2010).

Anderson \& Krathwohl (2010) memetakan keterampilan berpikir terdiri atas beberapa tingkat, yaitu: kemampuan mengetahui pada tingkat $\mathrm{C} 1$, memahami pada tingkat $\mathrm{C} 2$, menerapkan pada taraf C3, menganalisis pada tahap C4, mengevaluasi pada level C5, dan sebagai puncaknya, kemampuan mengkreasi pada leel C6. Level C1 sampai C3 diklasifikasikan ke dalam keterampilan berpikir levelrendah. levelC4 hingga C6 termasuk keterampilan berpikir pada tingkat tinggi (Narayanan and Adithan 2015).

Narayanan juga menyatakan bahwa ranah kognitif: mengetahui, memahami, menerapkan diklasifikasikan ke dalam keterampilan.Berdasar pendapat-pendapat tersebut, dapat diketahui bahwa berpikir tingkat tinggi merupakan proses kritis sertamanipulatif dalam mengkonstruksi pengetahuan baru. Proses ini terpetakan ke dalam beberapa dimensi berpikir. Keterampilan berpikir tingkat tinggi yang dipakai pada penelitian ini sesuai den mengacu kepada pendapat Narayanan\& Adithan (2015).

Pada dunia pendidikan, konteks keterampilan berpikir tingkat tinggi diimplikasikan dalam proses pembelajaran secara sistematis. Implikasi juga diterapkan secara berjenjang dariPAUD hingga perguruan tinggi. Pada jenjang SD, berpikir tingkat tinggi menjadi salah satu tolok ukur keberhasilan proses pendidikan.

Penelitian programme for international student assessmenttahun 2018 menyatakan keterampilan berpikir tingkat tinggi di Indonesia belum memuaskan. Dari tiga bidang ilmu yang diukur, kemampuan membaca siswa Indonesia masih tergolong paling rendah jika dibandingkan dengan kemampuan matematika dan sains. Bahkan, sebagaimana hasil publikasi OECD, skor kemampuan membaca siswa Indonesia pada PISA 2018 terendah jika dibandingkan dengan skor pada tahun 2015 dan 2012. Hal ini menjadi tantangan dalam pembelajaran, khususnya pembelajaran bahasa (Wardhana dkk., 2020).

Ejaan merupakan salah satu materi pokok dalam pembelajaran tematikdi SD. Apalagi, pembelajaran bahasa merupakan penghela antarmuatan pelajaran. Ketepatan penggunaan ejaan merupakan dasar implementasi bahasa Indonesia yang baik dan benar pada jenjang selanjutnya. Ejaan merupakan semuakaidah berkaitan dengan lambang bunyi, pengujaran dan interrelasi antarlambang (Prihantini 2015). Ejaan merupakan aturan dalam penulisan yang berlaku pada 
bahasa Indonesia (Rahmaningsih 2016). Ejaan dalam bahasa Indonesia memiliki pedoman pokok yang mendasarinya, yakni Pedoman Umum Ejaan Bahasa Indonesia atau yang biasa disebut PUEBI. Ejaan dalam PUEBI mencakup penggunaan huruf, kaidah penulisan kata, kaidah pemakaian tanda baca, dan tata cara penulisan unsur serapan. Pedoman tersebut tercantum dalam Peraturan Menteri Pendidikan dan Kebudayaan Nomor 50 Tahun 2015. Aturan tersebut mengisyaratkan bahwa pemerintah serius dalam mengaturpenggunaan ejaan bahasa Indonesia.

Sayangnya, kondisi di lapangan belum sejalan dengan keseriusan pemerintah. Penelitian menunjukkan bahwa karangan siswa kelas 2 SD masih banyak terdapat kesalahan dari aspek ejaan, baik penggunaan huruf capital, maupun tanda baca Praheto \& Wijayanti, 2020). Hasil ini didukung olehkajian need analysis yang dilakukan peneliti pada focus group discussion dengan guru kelas di Kabupaten Semarang.

Berdasarkanpada hasil focus group discussion tersebut dapat diketahui bahwa kemampuan penggunaan ejaan siswa SD di Kabupaten Semarang kurang memuaskan. Terdapat beberapa faktor yang memengaruhi hal tersebut. Pertama, guru kebingungan dalam mengembangkan materi ejaan pada pembelajaran tematik pada struktur kurikulum 2013. Adanya perubahan paradigma pembelajaran tematik di SD membuat guru bingung kapan akan mengajarkan ejaan. Kedua, guru belum mengembangkan pembelajaran ejaan.Kompetensi dasar tentang ejaan muncul pada kelas 2 dan kelas 5. Guru tidak mengajarkan ejaan pada kompetensi dasar yang tidak menekankan aspek ejaan. Hal ini tentu berimplikasi pada rendahnya kualitas pembelajaran ejaan di SD.

Persiapan yang matang akan memudahkan proses belajar siswa (Wahyuni and Mustadi 2016). Hasil temuan lapangan menunjukkan bahwa guru dalam pembelajaran tematik SD di Kabupaten Semarang kurang mengintegrasikan keterampilan dalam berpikir tingkat tinggi dan pembelajaran ejaan (Winarni, Sufanti, and Markhamah 2019). Hasil ini diperinci dengan $79 \%$ guru memberikan respon kadangkadang melakukan persiapan pembelajaran ejaan, $61 \%$ jarang melaksanakan pembelajaran ejaan, 57\% kadang-kadang mengintegrasikan proses berpikir tingkat tinggi dalam pembelajaran ejaan, dan $51 \%$ sering mengukur keterampilan berpikir tingkat tinggi dalam evaluasi pembelajaran ejaan.

Terdapat beberapa penelitian yang relevan dalam mengkaji perangkat pembelajaran. Salah satu penelitian di antaranya penelitian tentang peningkatan HOTS materi bangun ruang sisi datar melalui pengembangan perangkat pembelajaran (Riadi and Retnawati 2014). Penelitian lainnya adalah penelitian mengenaipelatihan keterampilan berpikir pemahaman konsep materi sifat cahaya melalui pengembangan perangkat pembelajaran (Sukoco 2019). Berikutnya, penelitian mengenai pengembangan perangkat pembelajaran berbasis sosiokultural bagi siswa SD (Erviana 2016).

Penelitian yang berkaitan dengan pengukuran berpikir tingkat tinggi mengenai butir soal pilihan ganda dan isian untuk mengukur kemampuan HOTS siswa juga sudah dilakukan(Yuliandini, Hamdu, and Respati 2019).

Berdasarkan pemaparan di atas, dapat dinyatakan memecahkan masalah pembelajaran ejaan di lapangan dapat dilakukan dengan pengembangan perangkat pembelajaran. Tujuan penelitian ini adalah menghasilkan perangkat pembelajaran ejaan yang valid untuk meningkatkan kemampuan berpikir tingkat tinggi, menghasilkan perangkat pembelajaran ejaan yang praktis untuk meningkatkan kemampuan berpikir tingkat tinggi, dan menghasilkan perangkat 
pembelajaran ejaan yang efektif untuk meningkatkan kemampuan berpikir tingkat tinggi.

\section{Metode}

Penelitian ini merupakan penelitian pengembangan. Model pengembangan, yang terdiri atas 10 langkah, merupakan prosedur penelitian yang diterapkan dalam penelitian ini(Borg and Gall 1984). Rangkaian prosedur penelitian berupa studi pendahuluan dan pengumpulan informasi, perencanaan, pengembangan draf produk, uji coba awal, perbaikan uji coba awal, uji coba lapangan terbatas, perbaikan uji coba lapangan terbatas, uji coba operasional, penyampurnaan, dan diseminasi. Penentuan ukuran validitas berdasarkan hasil validasi ahli pembelajaran dan ahli bahasa.Kepraktisan diperoleh dari respon guru dan respon siswa terhadap pembelajaran. Keefektifan diketahui dari signifikansi perbandingan kelas eksperimen dengan kelas kontrol.

Siswa kelas IV SDIT Izzatul Islam Getasan Kabupaten Semarang merupakan subjek penelitian. Pemilihan subjek kelas IV dimaksudkan agar hasil pengembangan dapat diterapkan oleh guru dalam semua pembelajaran; tidak hanya pada pembelajaran KD ejaan. Teknik pengumpulan data berupa focused group discussion (FGD) dan penilaian produk. Teknik analisis data menggunakan teknik deskriptif kuantitatif dan deskriptif kualitatif.Instrumen yang digunakan yaitu skala penilaian produk, skala respons guru, respons siswa, dan tes tertulis. Penentuan kualitas penilaian dilakukan dengan rumus berdasar pada pendapat Akbar (Akbar 2013).

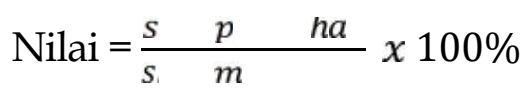

Kualitas perangkat pembelajaran yang dikembangkan dinilai dengan criteria sebagaimana tersaji pada tabel 1 .
Untuk mengetahui kepraktisan produk digunakan skala respon guru dan skala respon siswa selama proses pembelajaran dengan kriteria penilaian skala empat.

Kriteria skala penilaian tersaji pada tabel 2. Penilaian dikatakan memenuhi kriteria jika kategori minimal yang dicapai adalah baik (Widoyoko, 2009: 110).

Tabel 1

Kriteria Kualitas Perangkat Pembelajaran

$\begin{array}{cc}\text { Nilai } & \text { Predikat } \\ 85,01-100 & \begin{array}{c}\text { Sangat valid, bisa } \\ \text { diterapkan tanpa } \\ \text { perbaikan } \\ \text { Cukup valid, perlu } \\ \text { perbaikan kecil }\end{array} \\ 50,01-85 & \begin{array}{c}\text { Kurang valid, disarankan } \\ \text { tidak digunakan karena } \\ \text { perlu banyak perbaikan } \\ \text { Tidak valid, tidak boleh } \\ \text { digunakan }\end{array} \\ & \end{array}$

(Akbar 2013)

Tabel 2. Kriteria Skala Penilaian

\begin{tabular}{ccc}
\hline Kategori & Bobot Nilai & Persentase \\
\hline Sangat Baik & 4 & $82-100$ \\
Baik & 3 & $63-81$ \\
Tidak Baik & 2 & $44-62$ \\
Sangat Tidak & 1 & $25-43$ \\
Baik & &
\end{tabular}

(Akbar 2013)

Untuk mengukur keefektifan produk, pada uji coba operasional dilakukan analisis skor signifikansi perbedaan kelas eksperimen dan kelas kontrol. Langkah dalam menganalisis yaitu: (1) melakukan uji normalitas menggunakan rumus KolmogorofSmirnov, (2) melakukan uji homogenitas, dan (3) melakukan uji t. Apabila dalam penelitian data ditemukan tidak normal, dilakukan alternatif uji beda menggunakan uji $\mathrm{t}$ tes tidak 
berpasangan. Uji t tes ini menggunakan uji Mann-Whitney (Dahlan 2015).

\section{Hasil dan Pembahasan}

\subsection{Hasil Penelitian}

Berdasarkan hasil focused group discussion dengan guru kelas di Kabupaten Semarang, diketahui bahwa guru kebingungan dalam mengembangkan materi ejaan pada pembelajaran tematik pada struktur kurikulum 2013. Adanya perubahan paradigma pembelajaran tematik di SD membuat guru bingung kapan akan mengajarkan ejaan. Selain itu, guru belum mengembangkan pembelajaran ejaan. Guru tidak mengajarkan ejaan pada kompetensi dasar yang tidak menekankan aspek ejaan. Hal ini tentu berimplikasi pada rendahnya kualitas pembelajaran ejaan di SD.

Pada tahap studi pustaka, peneliti melakukan kajian terhadap teori tentang perangkat pembelajaran, pembelajaran ejaan, dan kemampuan berpikir tingkat tinggi. Kegiatan yang dilakukan adalah menganalisis buku, jurnal, dan Peraturan Menteri Pendidikan dan Kebudayaan (Permendikbud). Berdasarkan pada hasil studi pendahuluan, dapat disimpulkan bahwa guru membutuhkan perangkat pembelajaran ejaan untuk meningkatkan kemampuan berpikir tingkat tinggi siswa yang tidak hanya pada KD ejaan.

Penelitian ini dilakukan pada kelas IV SDIT Izzatul Islam Getasan Kab. Semarang. Pemilihan jenjang kelas IV ini bertujuan agar penelitian ini dapat digunakan sebagai referensi bagi guru bahwa pembelajaran ejaan secara otomatis mengiringi setiap kegiatan pembelajaran. Pembelajaran ejaan tidak hanya diajarkan pada kompetensi dasar yang mengandung materi ejaan secara tersurat saja.

Penelitian yang dimaksud diawali dengan pengembangan draf produk perangkat pembelajaran ejaan untuk meningkatkan kemampuan berpikir tingkat tinggi siswa.
Perangkat yang dikembangkan berupa silabus, Rencana Pelaksanaan Pembelajaran (RPP), Lembar Kerja Peserta Didik(LKPD), dan penilaian. Pengembangan draf produk berdasarkan hasil kajian teori yang menyimpulkan 4 prinsip pembelajaran ejaan untuk meningkatkan kemampuan berpikir tingkat tinggi siswa SD.

Pertama, perangkat pembelajaran ejaan hendaknya berorientasi pada kompetensi abad XXI. Perangkat yang disusun bertujuan untuk menyiapkan siswa menghadapi tantangan abad XXI, yaitu berpikir kritis, kolaboratif, komunikatif, dan kreatif. Perangkat yang dikembangkan disesuaikan dengan karakteristik kompetensi dasar dan materi yang akan dibahas. Oleh karena itu, pembelajaran ejaan dikemas mengikuti perkembangan zaman agar sesuai dengan kebutuhan siswa

Prinsip pembelajaran ejaan yang kedua sistematis dan saling berkaitan antarkomponen. Bahasa Indonesia sebagai penghela antarmuatan pelajaran di SD menjadi tantangan bagi ahli bahasa agar mampu merengkuh seluruh komponen ilmu pengetahuan secara bersama-sama. Ejaan diimplikasikan ke semua pembelajaran, tidak terbatas pada muatan pembelajaran Bahasa Indonesia saja. Penguasaan ejaan dibutuhkan di semua aspek ilmu pengetahuan, khususnya yang berkaitan dengan kegiatan tulismenulis.

Ketiga, membimbing siswa berpikir integralistik. Proses pembelajaran ejaan disajikan secara menyeluruh, mulai dari hal mendasar hingga tataran kreasi. Pembelajaran membimbing siswa untuk menganalisis, mensintesis konsep tertentu, mengasosiasi, hingga menarik kesimpulan menuju ide kreatif dan produktif. Ketercapaian prinsip ini akan terlihat pada akhir pembelajaran. Penilaian pembelajaran merupakan cermin ketercapaian kemampuan berpikir siswa. Siswa yang berpikir integralistik akan lebih 
mudah memecahkan masalah sehari-hari, khususnya yang berkaitan dengan ejaan. Siswa didorong lebih kritis dalam menyimak teks yang berkaitan dengan ejaan pada pemakaian bahasa dalam kehidupan seharihari.

Keempat, pembelajaran dilaksanakan secara tematik terpadu. Terpadu dalam prinsip ini dimaksudkan pada keterpaduan cakupan materi. Akan tetapi, penekanan tetap pada satu aspek yang menjadi fokus pembelajaran. Ejaan diimplikasikan ke semuapembelajaran, tidak terbatas pada muatan pembelajaran Bahasa Indonesia saja. Penguasaan ejaan dibutuhkan pada semua aspek ilmu pengetahuan, khususnya yang berkaitan dengan kegiatan tulis-menulis.

Draf perangkat pembelajaran yang dikembangkan berdasarkan keempat prinsip tersebut selanjutnya divalidasi oleh ahli. Validasi ahli bertujuan untuk mengukur kebenaran atau keabsahan produk yang dikembangkan. Terdapat 2 ahli yang terlibat, yaitu ahli pendidikan dan ahli bahasa.

Berdasar hasil penilaian ahli, dapat disimpulkan bahwa perangkat pembelajaran silabus menurut ahli materi sangat valid dan tidak perlu revisi. RPP menurut ahli materi juga sangat valid dan tidak perlu revisi. LKPD menurut ahli materi perlu dilakukan sedikit revisi pada tampilan.Revisi tampilan LKPD meliputi pentingnya penambahan gambar ilustrasi dan tampilan warna yang beragam. Hal ini bertujuan agar LKPD sesuai dengan karakteristik siswa kelas IV SD. Penilaian juga dapat diujicobakan tanpa revisi.Hasil tersebut dapat dilihat pada tabel 3.

Tabel 3

Validasi Perangkat Pembelajaran oleh Ahli

\begin{tabular}{llll}
\hline No. & $\begin{array}{l}\text { Perangkat } \\
\text { Pembelajaran }\end{array}$ & $\%$ & $\begin{array}{l}\text { Kategori } \\
\text { Kelayakan }\end{array}$ \\
\hline 1. & Silabus & 91,77 & $\begin{array}{l}\text { Sangat } \\
\text { Valid }\end{array}$
\end{tabular}

\begin{tabular}{llrl} 
2. & RPP & 90,52 & $\begin{array}{l}\text { Sangat } \\
\text { Valid } \\
\text { Valid }\end{array}$ \\
3. & LKPD & 98,33 & Pangat \\
4. & Penilaian & 95,00 & $\begin{array}{l}\text { Sangal } \\
\text { Valid }\end{array}$ \\
\hline
\end{tabular}

\subsection{Analisis Data Hasil Uji Coba Awal}

Uji coba awal dilaksanakan di kelas IVB SDIT Izzatul Islam Getasan dengan subjek 3 orang. Pemilihan subjek ini dilakukan dengan memperhatikan perbedaan kemampuan siswa. Hasil yang diperoleh pada uji coba awal berupa data keefektifan perangkat pembelajaran. Pengukuran keefektifan perangkat pembelajaran dilakukan dengan pemberian skala respons guru terhadap keterlaksanaan perangkat pembelajaran, skala respons siswa terhadap pelaksanaan pembelajaran, dan tes tertulis.

Berdasar hasil uji coba awal perangkat pembelajaran dapat diketahui bahwa perangkat pembelajaran terbukti efektif dalam mengembangkan kemampuan berpikir tingkat tinggi.

Setelah produk selesai divalidasi oleh ahli, selanjutnya dilaksanakan pembelajaran ejaan di sekolah menggunakan perangkat yang sudah dikembangkan. Uji coba dilakukan sebanyak tiga kali, yaitu uji coba awal, ujicoba lapangan, dan uji coba operasional. Uji coba bertujuan untuk mengukur kepraktisan perangkat pembelajaran dalam memberikan pengalaman belajar ejaan dalam meningkatkan kemampuan berpikir tingkat tinggi siswa SD. Pengukuran keefektifan berdasarkan kuesioner yang diberikan kepada guru dan siswa.Kepraktisan menurut respon guru diukur berdasarkan kesan, kemanfaatan, dan keefektifan keterlaksanaan perangkat pembelajaran.Respon guru terhadap pelaksanaan pembelajaran ejaan yang dikembangkan sangat baik pada uji coba 
awal dan baik pada uji coba lapangan danuji coba operasional.

Selain dari skala respon guru, kepraktisan produk diperoleh berdasarkan hasil skala respon siswa terhadap keterlaksanaan perangkat pembelajaran. Penilaian skala respon siswa meliputi: kesan proses pembelajaran, materi, cara pembelajaran, dan keberlanjutan pembelajaran. Berdasarkan skor aktual skala respon siswa, dapat diketahui bahwa total skoraktual mengindikasikan perangkat berkategori baik.

Hasil penilaian siswa mengenai ejaan pada uji coba selanjutnya dianalisis menggunakan uji statistika untuk mengukur keefektifan perangkat pembelajaran ejaan yang dikembangkan dalam meningkatkan kemampuan berpikir tingkat tinggi. Uji normalitas menggunakan KolmogorovSmirnov. Berdasarkan hasil uji normalitas, diketahui bahwa data dalam penelitian ini ditemukan tidak normal. Oleh karena itu, dilakukan uji beda menggunakan MannWhitney. Hasil uji beda menggunakan MannWhitney tersaji pada tabel 4 .

Tabel 4

Uji Beda menggunakan Mann-Whitney

\begin{tabular}{cc}
\hline Test Statistics & $\begin{array}{c}\text { Uji Coba } \\
\text { Operasional }\end{array}$ \\
\hline Mann-Whitney U & 175,500 \\
\hline Wilcoxon W & 500,500 \\
Z & $-2,869$ \\
Asymp. Sig. (2-tailed) &, 004 \\
\hline
\end{tabular}

Berdasarkan tabel 4 dapat diketahui bahwa terdapat signifikansi perbedaan antara kelas eksperimen dengan kelas kontrol. Signifikansi perbedaannya adalah 0,004 . Dengan uji Mann-Whitney, diperoleh nilai $p$ $0,004<0,05$. Secara statistik, dapat disimpulkan bahwa terdapat perbedaan antara kelas kontrol dan kelas eksperimen. Hal ini menunjukkan bahwa terdapat perbedaan penguasaan berpikir tingkat tinggi antara kelas eksperimen dan kelas control setelah dilakukan pembelajaran dengan mengaplikasikan perangkat pembeljaran ejaan yang dikembangkan oleh peneliti.

\subsection{Pembahasan}

Kualitas pembelajaran ejaan yang kurang berimplikasi pada kurang menggembirakannya hasil pembelajaran ejaan di SD. Selain belum dikuasainya konsep pembelajaran ejaan oleh guru, kurangnya perangkat pembelajaran yang memadai menjadi salah satu penyebab pembelajaran ejaan di SD. Pembelajaran yang berorientasi pada kecakapan abad XXI saat ini menjadi sebuah keniscayaan. Ejaan yang dipandang serius oleh pemerintah dengan dilandasi oleh permendikbud mengenai PUEBI membuat ketersediaan perangkat pembelajaran ejaan menjadisebuah kebutuhan dalam pembelajaran ejaan di SD.

Hasil analisis lapangan juga menguatkan bahwa guru SD di lapangan masih belum maksimal dalam mempersiapkan pembelajaran ejaan. Padahal, ejaan BahasaIndonesia merupakan bagian penting dari suatu bahasa. Penerapan ejaan Bahasa Indonesia merupakan salah satu wujud cinta tanah air.Bahasa Indonesia sebagai bahasa pemersatu dengan ejaan sebagai salah satu kajiannya tentu harus dikuasai oleh semua penuturnya, termasuk oleh siswa.

Perangkat pembelajaran ejaan yang dikembangkan berupa silabus, RPP, LKPD, dan penilaian pada tema "Peduli Terhadap Makhluk Hidup" subtema "Ayo, cintai lingkungan!" di kelas IV SD menurut ahli materi dan ahli pembelajarandinilai baik. Perangkat pembelajaran tersebut mempunyai konsep yang jelas, disajikan dengan petunjuk yang dapat dipahami, serta materi yang sesuai dengan kompetensi inti dan kompetensi dasar. Secara teknik kelengkapan pembelajaran yang berupa silabus dan RPP disusun dengan memperhatikan kelengkapan 
komponan yang tertuang dalam Permendikbud Nomor 22 tahun 2016 tentang standar Proses Pendidikan Dasar dan Menengah dan secara subtansial perangkat pembelajaran disusun berdasarkan pembelajaran ejaan untuk meningkatkan kemampuan berpikir tingkat tinggi siswa SD.

Silabus yang dikembangkan dalam penelitian ini valid menurut ahli materi dan ahli pembelajaran. Persentase penilaian silabus menurut ahli materi adalah 85,26\%. Persentase skor silabus menurut ahli pembelajaran adalah 95,78\%. Hal ini membuktikan bahwa silabus memiliki kategori penilaian sangat baik dan tidak diperlukan revisi. Prosedur pengembangan silabus berupa garis besar rencana pembelajaran yang memuat berbagai jenis program perencanaan pembelajaran (Kunandar 2015). Komponen penting dalam silabus selanjutnya dikembangkan dalam bentuk RPP.

Pengembangan RPP dalam penelitian ini disesuaikan dengan Surat Edaran Mendikbud Nomor 14 Tahun 2019 tentang penyederhanaan RPP. RPP yang dikembangkan dalam penelitian ini terdiri atas 4 pembelajaran, yaitu RPP untuk pertemuan 1, pertemuan 3, pertemuan 4, dan pertemuan 6.Model pembelajaran yang digunakan variatif, yaitu Discovery Learning, Problem Based Learning, dan Project Based Learning yang ketiganya disesuaikan dengan karakter peserta didik kelas IV SD.

RPP dalam penelitian ini dikembangkan sesuai dengan kompetensi abad XXI yang mengedepankan 4C (Communication, Collaboration, Critical Thinking, And Creativity) dalam pembelajaran. Pengembangan RPP dengan mengintegrasikan $4 \mathrm{C}$ dalam pembelajaran sangatlah penting (Sasriyana and Kholiq 2020). RPP yang dikembangkan dalam penelitian ini valid menurut ahli materi dan ahli pembelajaran. Persentase penilaian RPP menurut ahli materi adalah 92,86\%. Persentase skor RPP menurut ahli pembe- lajaran adalah 93,57\%. Hal ini membuktikan bahwa RPP yang dikembangkan memiliki kategori penilaian sangat baik dan tidak diperlukan revisi.

Pengembangan perangkat pembelajaran ini memenuhi pendapat Pratama dkk. (2017) yang menyatakan bahwa guru sangat membutuhkan perangkat pembelajaran menulis deskriptif. Perangkat yang dikembangkan berupa silabus, RPP, LKPD, video pembelajaran, soal tes danbuku petunjuk guru (Pratama, Nuryatin, and Mardikantoro 2017).

Pengembangan LKPD dan penilaian mengacu pada Permendikbud nomor 23 Tahun 2016 tentang Standar Penilaian Pendidikan. Pengembangan LKPD dan penilaian mengacu pada tujuan pembelajaran yang tertuang dalam RPP. Perangkat pembelajaran yang dikembangkan ini mengembangkan kompetensi dasar 3.3 dan 4.3 pada pembelajaran tematik materi wawancara. Kompetensi dasar 3.3 dikembangkan ke dalam 8 indikator dan kompetensi dasar 4.3 dikembangkan ke dalam 4 indikator.

LKPD yang dikembangkan dalam penelitian ini terdiri atas 6 LKPD yang disesuaikan dengan tujuan pembelajaran dilengkapi kegiatan yang memungkinkan peserta didik menyelesaikan masalah secara berkelompok. Masalah yang disajikan dalam LKPD dipilih sesuai dengan peningkatan kemampuan berpikir tingkat tinggi.

Pengembangan LKPD yang menggunakan pendekatan tematik sebaiknya kontekstual sesuai dengan kehidupan seharihari (Sasmito and Mustadi 2016). LKPD yang dikembangkan dalam penelitian ini valid menurut ahli materi dan ahli pembelajaran. Persentase penilaian LKPD menurut ahli materi adalah $82,22 \%$. Persentase skor LKPD menurut ahli pembelajaran adalah 94,44\%. Hal ini membuktikan bahwa LKPD yang 
dikembangkan memiliki kategori penilaian baik.

Instrumen penilaian berbentuk tes tertulis yang dikembangkan dalam penelitian ini bertujuan mengukur ketercapaian kompetensi peserta didik pada materi ejaan dan kemampuan berpikir tingkat tinggi siswa.Soal yang dikembangkan berbentuk pilihan ganda sebanyak 5 butir dari pembelajaran 1, 7 butir dari pembelajaran 3, 6 butir daripembelajaran 4, dan 5 butir dari pembelajaran 6 .

Ketepatan suatu tes adalah mengukur kemampuan siswa (Kusaeri and Suprananto 2012). Menurut ahli materi, lembar evaluasi yang dikembangkan berada pada kategori sangat valid, yaitu 94,29\%. Kategori sangat baik juga diberikan oleh ahli pembelajaran dengan skor 95,71\% pada lembar penilaian.

Kepraktisan merupakan kriteria kualitas perangkat pembelajaranditinjau dari kemudahan guru dan siswa menggunakan perangkat pembelajaran yang digunakan (Nieveen and Plomp 2010). Kepraktisan perangkat pembelajaran ejaan yang dikembangkan dalam meningkatkan kemampuan berpikir tingkat tinggi tercermin dari hasil respon guru dan siswa selama proses pembelajaran dan setelah proses pembelajaran. Kesan terhadap pembelajaran ejaan sangat baikpada uji coba. Penilaian aspek manfaat meningkat sangat baik pada uji coba operasional dansangat baik pada tahap uji coba.

Penilaian skala respon siswa meliputi kesan prosespembelajaran, materi, cara pembelajaran, dan keberlanjutan pembelajaran. Berdasarkan skor aktual skala respon siswa, dapat diketahui bahwa total skoraktual mengindikasikan perangkat berkategori baik.

Keefektifan dalam konteks pembelajaran diukur dari keterkaitan antara tujuan dan hasil yang diperoleh dari haril belajar (Daryanto 2013). Lembar penilaian juga efektif meningkatkan kemampuan berpikir tingkat tinggi siswa. Berdasar hasil uji coba awal, rerata persentase kemampuan berpikir tingkat tinggi siswa $82 \%$ dan berkategori baik. Pada uji coba lapangan, persentase kemampuan berpikir tingkat tinggi siswa juga berkategori baik dengan persentase $82 \%$.

Hasil uji coba lapangan dengan uji beda menggunakan tes Mann-Whitney diperoleh nilai p 0,004<0,05. Secara statistik, dapat disimpulkan bahwa terdapat perbedaan kemampuan berpikir tingkat tinggi antara kelas kontrol dan kelas eksperimen.

Hasil penelitian ini mendukung penelitian-penelitian sebelumnya, yakni bahwa integrasi kemampuan berpikir tingkat tinggi dalam pembelajaran sangat penting (Wardany dkk., 2017), (Faiqoh dkk., 2019), (Hugerat and Kortam 2014), (Alsowat 2016), (Ganapathy dkk., 2017).

Penelitian ini juga relevan dengan penelitian yang yang menyatakan bahwa kemampuan berpikir tingkat tinggi memiliki pengaruh dalam banyak hal yang berkaitan dengan siswa. Kemampuan berpikir tingkat tinggi juga berpengaruh terhadap tingkat kecerdasan dengan kemampuan literasi sains siswa SMP (Yuriza dll., 2018). Pendekatan pembelajaran saintifik berorientasi Higher Order Thingking Skillsberpengaruh terhadap pemahaman belajar siswa (Putra and Hanggara 2018).

Pengambangan perangkat pembelajaran juga dapat meningkatkan karakter siswa karena karakter kreatif merupakan bagian dari kemampuan berpikir tingkat tinggi (Wahyuni and Mustadi 2016). Dalam melaksanakan pengembangan, integrasi kemampuan berpikir tingkat tinggi dalam pembelajaran juga penting memperhatikan metodologi pengembangan yang digunakan (Fanani and Kusmaharti 2014).

\section{Simpulan}

Berdasarkan hasil penelitian dan pembahasan, dapat disimpulkan bahwa perangkat pembelajaran ejaan yang 
dikembangkan valid meningkatkan kemampuan berpikir tingkat tinggi dengan kategori sangat baik berdasarkan penilaian ahli pendidikan dan ahli bahasa. Perangkat pembelajaran yang dikembangkan valid untuk digunakan berdasarkan hasil uji validitas yang dilakukan oleh ahli materi dan ahli pembelajaran.

Selain itu, perangkat pembelajaran ejaan yang dikembangkan dinilai praktis menurut skala respon guru dan respon siswa dalam meningkatkan kemampuan berpikir tingkat tinggi dengan kategori baik.

Perangkat pembelajaran ejaan jugadinilai efektif meningkatkan kemampuan berpikir tingkat tinggi dengan pengaruh sangat signifikan antara kelas kontrol dan kelas eksperimen. Uji statistika menggunakan Mann-Whitney menunjukkan $\mathrm{p}<0,05$ yang membuktikan bahwa terdapat perbedaan signifikan kemampuan berpikir tingkat tinggi antara siswa yang mendapat perlakuan dan tidak mendapat perlakuan.

\section{Daftar Pustaka}

Akbar, Sa' dun. 2013. Instrumen Perangkat Pembelajaran. Bandung: Remaja Rosdakarya.

Alsowat, Hamad. 2016. “An EFL Flipped Classroom Teaching Model: Effects on English Language Higher-Order Thinking Skills, Student Engagement and Satisfaction." Journal of Education and Practice 7 (9): 108-21. https:/ / doi.org/10.5539/elt.v9n9p166

Anderson, Lorin W., and David R. Krathwohl, eds. 2010. Kerangka Landasan untuk Pembelajaran, Pengajaran dan Asesmen (Revisi Taksonomi Pendidikan Bloom). Yogyakarta: Pustaka Pelajar.

Baryadi, Isodarus Praptomo. 2017. "Pembelajaran Bahasa Indonesia
Berbasis Teks." Jurnal Ilmiah

Kebudayaan Sintesis 11 (1): 1-11.

Borg, Walter R., and Meredith D. Gall. 1984.

"Educational Research: An

Introduction." British Journal of

Educational Studies 32 (3): 274.

https:/ / doi.org/10.2307/3121583

Dahlan, Muhammad Sopiyudin. 2015.

Statistik untuk Kedokteran dan Kesehatan.

Jakarta: Epidemiologi Indonesia.

Daryanto. 2013. Inovasi Pembelajaran Efektif.

Bandung: Yrama Widya.

Erviana, Vera Yuli. 2016. “Pengembangan

Perangkat Pembelajaran Berbasis

Sosiokultural bagi Siswa SD." Jurnal

Prima Edukasia 4 (2): 222-32.

https:/ / doi.org/10.21831/jpe.v4i2.897 0

Faiqoh, Annisa Nur, Sony Irianto, and Subuh Anggoro. 2019. "Pengembangan LKPD Matematika Berbasis Higher Order Thingking Skills (HOTS) Materi Bangun Ruang Kelas V Sekolah Dasar." 2 (2): 103-6.

Fanani, Achmad, and Dian Kusmaharti. 2014. "Pengembangan Pembelajaran Berbasis HOTS (Higher Order Thinking Skill) di Sekolah Dasar Kelas V." Jurnal Pendidikan Dasar.

Ganapathy, Malini Ganapathymalini, Manjet Kaur Mehar Singh, Sarjit Kaur, and Liew Wai Kit. 2017. "Promoting Higher Order Thinking Skills via Teaching Practices." 3L: Language, Linguistics, Literature.

https:/ / doi.org/10.17576/3L-20172301-06

Hugerat, Muhamad, and Naji Kortam. 2014. “Improving Higher Order 
Thinking Skills among Freshmen by Teaching Science through Inquiry." Eurasia Journal of Mathematics, Science and Technology Education.

https:/ / doi.org/10.12973/eurasia.2014 $.1107 \mathrm{a}$

Istiqomah. 2018. Pembelajaran Dan Penilaian High Order Thinking Skills. Surabaya: Pustaka Mediaguru.

KBBI. 2020. “Ejaan.”

Kunandar. 2015. Penilaian Autentik (Penilaian Hasil Belajar Peserta Didik Berdasarkan Kurikulum 2013.

Kusaeri, and Suprananto. 2012. Pengukuran dan Penilaian Pendidikan. Yogyakarta: Graha Ilmu.

Lestari, Reski. 2017. “Kesantunan Berbahasa Indonesia Siswa di Lingkungan SMP Negeri 10 Kendari." Jurnal Bastra 1 (4): 1-22. https://doi.org/10.33369/pgsd.10.1.11 $-17$

Narayanan, Sowmya, and M. Adithan. 2015. “Analysis Of Question Papers In Engineering Courses With Respect To Hots (Higher Order Thinking Skills)." American Journal of Engineering Education (AJEE) 6 (1): 1-10. https://doi.org/10.19030/ajee.v6i1.924 7

Nieveen, Nienke, and Tjeerd Plomp, eds. 2010. An Introduction to Educational Design Research. Netherlands Institute for Curriculum Development.

Praheto, Biya Ebi, and Dwi Wijayanti. 2020. "Analisis Gagasan Karangan Multikultural Siswa Kelas 2 SD Negeri Timuran Yogyakarta." Jurnal Cakrawala Pendas 6 (1): 48-55. https:// doi.org/10.31949/jcp.v6i1.178 7

Pratama, Galih Suci, Agus Nuryatin, and Hari Bakti Mardikantoro. 2017. "Pengembangan Perangkat Pembelajaran Menulis Deskriptif dengan Pendekatan SAVI Berbantuan Video bagi Siswa SD." Journal of Primary Education.

Prihantini, Ainia. 2015. Master Bahasa Indonesia: Panduan Tata Bahasa Indonesia Terlengkap. Yogyakarta: Bentang Pustaka.

Puswitasari, Putri, Ali Sudin, and Dadan Djuanda. 2016. "Penerapan Model Bengkel Menulis (Writing Workshop) dengan Permainan Melingkari Ejaan untuk Meningkatkan Keterampilan Menulis Surat Undangan Ulang Tahun di Kelas V A SDN Rancamulya Kecamatan Sumedang Utara Kabupaten Sumedang." Jurnal Pena Ilmiah 1 (1): 901-10.

Putra, Rizka Andhika, and Agie Hanggara. 2018. "Pengaruh Pendekatan Pembelajaran Saintifik Berorientasi Higher Order Thingking Skills (HOTS) terhadap Pemahaman Belajar Siswa." Jurnal Penelitian Pendidikan dan Ekonomi 15 (2): 44-50.

Rahmaningsih, Pitasari. 2016. "Mengajarkan Ejaan pada Siswa SD." Jurnal Ilmiah Guru “COPE" 1 (20): 60-69.

Riadi, Arifin, and Heri Retnawati. 2014. "Pengembangan Perangkat Pembelajaran Untuk Meningkatkan HOTS pada Kompetensi Bangun Ruang Sisi Datar." Pythagoras: Jurnal Pendidikan Matematika 9 (2): 126-35.

Sasmito, Luncana Faridhoh, and Ali 
Mustadi. 2016. "Pengembangan Lembar Kerja Peserta Didik TematikIntegratif Berbasis Pendidikan Karakter pada Peserta Didik Sekolah Dasar." Jurnal Pendidikan Karakter 1 (1): 70-81.

Sasriyana, Ennoer, and Abd. Kholiq. 2020.

"Validasi Perangkat Pembelajaran Pbl

(Problem Based Learning) Berbantuan

Media 'Esl' pada Materi Alat Optik."

Inovasi Pendidikan Fisika 9 (1): 31-35.

Sriyanto. 2015. Seri Penyuluhan Bahasa

Indonesia Ejaan. Jakarta: Pusat

Pembinaan dan Pemasyarakatan

Badan Pengembangan dan Pembinaan

Bahasa Kementerian Pendidikan dan

Kebudayaan.

Sukoco, Sukoco. 2019. “Pengembangan

Perangkat Pembelajaran Berbasis

Pendekatan Saintifik untuk Melatihkan

Keterampilan Berpikir dan

Pemahaman Konsep Siswa pada

Materi Sifat Cahaya Kelas V SD."

Jurnal Review Pendidikan Dasar $\square$ : Jurnal

Kajian Pendidikan dan Hasil Penelitian

5(2):1-10.

https://doi.org/10.26740/jrpd.v5n2.p9

86-995

Tarigan, Henry Guntur. 2009. Pengajaran

Ejaan Bahasa Indonesia. Bandung:

Penerbit Angkasa.

Wahyuni, Mei, and Ali Mustadi. 2016.

"Pengembangan Perangkat Pembelajaran Collaborative Learning Berbasis Kearifan Lokal Untuk Meningkatkan Karakter Kreatif dan Bersahabat." Jurnal Pendidikan Karakter 2 (6): 246-60. https:/ / doi.org/10.21831/jpk.v6i2.12056

Wardany, Kusuma, Sajidan, and Murni

Ramli. 2017. "Pengembangan Penilaian

untuk Mengukur Higher Order

Thinking Skills Siswa." Jurnal Inkuiri 6
(2): $1-16$.

https://doi.org/10.26714/jps.6.2.2018.

21-31

Wardhana, Dian Eka Chandra, Ria Ariesta, and Sarwit Sarwono. 2020. "Pelatihan

Penyusunan Soal Bahasa Indonesia Berorientasi HOT'S Untuk Guru SMP dan SMA." ABDI: Jurnal Pengabdian dan Pemberdayaan Masyarakat 2 (1): 1-10. https:// doi.org/10.24036/abdi.v2i1.29

Widoyoko, Eko Putro. 2009. “Evaluasi Pembelajaran Panduan Praktis Bagi Pendidik dan Calon Pendidik." Yogyakarta: Pustaka Pelajar.

Winarni, Main Sufanti, and Markhamah. 2019. “Persepsi Guru Terhadap Kemampuan Berpikir Tingkat Tinggi dalam Pembelajaran Ejaan di SD." Prosiding Konferensi Nasional Bahasa dan Sastra V.

Yuliandini, Nurul, Ghullam Hamdu, and Resa Respati. 2019. “Pengembangan Soal Tes Berbasis Higher Order Thinking Skill (Hots) Taksonomi Bloom Revisi di Sekolah Dasar." Pedadidaktika: Jurnal Ilmiah Mahasiswa Pendidikan Guru Sekolah Dasar 6 (1): 37 46.

Yuriza, Putri Emilia, Adisyahputra, and Diana Vivanti Sigit. 2018. “Hubungan Antara Kemampuan Berpikir Tingkat Tinggi dan Tingkat Kecerdasan dengan Kemampuan Literasi Sains pada Siswa SMP." Biosfer Jurnal Pendidikan Biologi 11 (1): 13-20. https:/ / doi.org/10.21009/biosferjpb.1 1-1.2 